\title{
Power and Politics as the Converter of Law Product in Indonesia
}

\author{
T. Subarsyah \\ Faculty of Law, Pasundan University, Jl. Lengkong Besar 68 Bandung, Indonesia.
}

\begin{abstract}
Power is one element of politics that is when the process of getting it. While the law is a product that is idealized as the consensus that resulting from the political process and confirmed by authority derived from the political process. Power relations, politics and the law can not be separated. Essentially, that law, political power and equally a social sub-system, which is an open system, a system that affects other systems. The Adagium can not be separated in terms of Das Sollen and Das Sein and proved that the law in fact determined by the configuration of politics and power.

State of law adherents of the principle of democracy can not be separated from the vortex of power that plays an important role in regulating human destiny. Even power is often juxtaposed with political concepts and understood that power is political.

The power of state is a power to regulate people in a life of state that includes the legislative, executive and judicial. Power is a means to carry out basic functions of the state in order to achieve the purpose of the State includes the sovereignty, authority and rights.

In general, the political concept plays a role in administering and controlling of the people's interests. Politics is a process in the formation and distribution of power in society through the realization of the decision-making process, especially in the state.

In fact many legal regulations become blunt due to the influence of power intervention. So that the law can not afford sharply downward tackle arbitrariness. In the end, justice becomes vague and rhetoric and can not as a guide. In Indonesia, many law products that are based on the interests of the ruler who hold the dominant power. That law is no longer sterile from sub system of society because power is not uncommon to approach politics over law-making and implementation.

Correlation of law and power are often a conflict of interest that seemed to be never-ending. Authority often intervene against the law, both when the legal establishment and implementation. Empirical facts above interventions often befall major cases involving the elite of the country.

While power in the formation of legal products are closely related to the power holders. When the New Order regime all law products that produced were authoritarian. In Reform Era, law products are nearly equal to the condensed power of the rulers. Correlation between law and power are clear. Both dimensions are different but have the same pragmatic and show linkages. In principle, legal products made ruler is the resultant of the ruler should be implemented consistently, as if the authorities as a control in limiting power.
\end{abstract}

Keyword: Power, Law, Politics.

\section{Introduction}

State of law with democratic principle cannot be separated from power that regulates the fate of mankind. Power is often juxtaposed with the concept of politics. In other words, power is politics. Relation between law and power have mutual-influence. However, law will lose its power when there is a conflict so the law energy is often defeated by the power energy. As a result, normative law depends on 
who is in power. Therefore, state has a power to control its society, including in legislative, executive, and judicative. Power, in this case, is a tool to achieve the state goal, including sovereignty, authority, and rights. In general, politic concept plays a role in manage and control the society life. As politic relates to people interest and leadership, it is very close to the concept of power.Politic is a process to form and distribute the power in society, through the realization of decision making process especially in state. John Austin in Rahardjo (2006) states that law is the order of the ruler of the state, and its essence lies in that order [1]. Power, politic and law form relevant link in the state. Unfortunately, power becomes dominant. The function of law weakens due to the intervention of power. A strict law is only applies to the down which it cannot control the arbitrary. As a result, justice becomes vague. It cannot be guidance.

In Indonesia, most of the product of law is based on the authority's power. In this case, law is no longer free from society sub-system.Power sometimes does political approach to the law implementation. Thus, the elements (power, politic, or law) becoming more supremative in sub-system are absurd.

\section{Literature Review}

\subsection{Power}

Robert Mac Iver defines power as an ability to control others behavior. It can be done directly by giving the order, or indirectly by using the all the possibility ways. Power is relation between the ordering party and the ordered party. For instance, the President makes the regulation (subject of power), but he should obey hisformulated regulation (object of the power)[2]; Relating to the and Kaplan (1970) defines it as relationship between an individual and group to the other groups by which one of them is able to influence the other [3]; van Appledorn (2008) states that power is thepossibility to limit the other groups' behavior according to the controlling group objective [4]; Semetko and Valkenburg (2000) assert that power is a relationship that limits the other groups' behavior [5]; Meanwhile, French (1995) classifies authority into five types: (1). Coercive Power; 2). Incentive power; (3). Legitimate power; (4). Expert; and (5) Referent power [6].

\subsection{Politics}

Politics is a series of process in the formation and distribution of power in society (such as process in making decision). It is an art and science to gain the power constitutionally or non-constitutionally. Politic is basically defined differently by many experts, such as: 1) Politics is society effort to create the benefits for all parties (The classical theory of Aristotle); 2) politics is a matter relating to government and state; 3) Politics is an activity that is leaded to gain and maintain the power in society; and 4) Politics is about the formulation process and public policy implementation.

Relating to the definition of politics in law, it is defined as state administration. As Garner (1979) states that politics is the science of the organization and administration of state. One of the main elements in politic is state [7]. The concept of state as the authority organization is proposed by Hans Kelsen (2006) says that state is regarded as group of individual or society living in a certain part of the earth and obeys the certain authority to form a nation, territory, a power, and a society. In the scope of state, power is the validity or the effectiveness of legal order that its unity is gained through territorial and society validity [8]. Then Hobes in Friedrich, 2008) defines power as a thing that exists today to gain the real benefits in the future [9].

Utrecht describes law as guidance of life (called norms or rules), the orders, and prohibition that govern discipline in society and should be obeyed by the members of society. Therefore, the violation of the guidance can cause an action from the government or ruler [10]. This is the normativeview from the law side. Philosophically and sociologically, law is related to the development of society relationship in 
a social system. Kusumaatmadja (1970) states that law is not only the overall principles or norms controlling the human life, but also institutions and processes that are implemented in reality [11].

\subsection{Law}

Kelsen depicts law as a system of norm; the statement emphasizes the aspect of "have to" (das solen). Norms are the product of human deliberative action. Kelsen, in this case, believes to the Hume's Theory that distinguishes the das sein and das solen. The theory states that, for das solen, drawing conclusion from factual event is impossible. Thus, Kelsen believes that law is the statement of "have to" that cannot be transformed in the natural acts. In Kelsen's point of view, the implemented law is not the exact law. This is pure theory of law which called positive law. The theory attempts to explain the law as well as clean up the explanation object from all the things related to the law [12]. Concerning this, Friedman (1990) asserts that the theory of law studies the essence of law that is related to the philosophy of law and political theory. As the discipline of law theory is not a part of independence science, it should be a part of law discipline independently [13].

McLeod (1999) affirms that law theory leads to theoretical analysis of the basic law, law regulation, or law institutionin general [14]. John Finch (1974) conveys that it is a study that learns the law characteristic and commons in law system. The aim is to analyze the basic elements that make it as a law and distinguish it from the other regulations [15]. Meanwhile, Jan Gijssels and Mark van Hocke (1982) assumes law theory as a study that explains the law itself. In this case, itis independent discipline by which the development is influenced and associated with the common law doctrine [16].

\section{Findings and Discussion}

\subsection{Law and Power in the Formation of Law Product}

Correlation of law and power are often a conflict of interest that seemed to be never-ending. Authority often intervene against the law, both when the legal establishment and implementation. Empirical facts above interventions often befall major cases involving the elite of the country.Power sometime intrudes the formation and the implementation of law when the law making process and its implementation. Empirical facts often occur on the big cases involving the country's elites. Power in the law product formation is strongly related to the authority holder. In the New Order, for instance, all the resulted law products have authoritarian character. This also occurs in this Reform era, by which the power has a big influence. In all law products, the influence of poweris strongly felt. Regarding this, Saldi Isra (2010) states that law product is one of function of legislative power [17]. Jimly A Shidique (2006) mentions four functions of power in legislative: 1) Legislative initiation; 2) Law making process; 3) the agreement of regulation draft; and 4) binding decision making on international law agreement and treaties or other legal binding documents [18].

The correlation between law and power is strongly obvious. These two different dimensions havesimilar characteristic, and interlinks one and another. In general, the law product made by power should be consistently implemented, and power should control its implementation.

\subsection{Politics and Law}

The causality between law and politics arises several questions: does law influence the politics, or vice versa? This implies that: 1) politic is arranged by law, and it should stay on the lower position; 2) politic is the determinant factor in law, considering law is a result of interacted political intentions; 3) Both politics and law are part of the society sub-system which stay in theequal position. The political decision product is law, so that it should comply with the law [19].

State's objective is determined by political process formulated in the preamble of the constitution as the supreme law in Indonesia (Constitution 1945). In PadmoWahyono's (1986) point of view, the law of 
politics is a basic policy that determines the direction, form, and content of the law. It is a law policy that is implemented nationally by the government or state [20]. As previously mentioned, this means that both politics and law are part of society sub-system. They are the result of political process which controls the society. Therefore, law can function as a tool that changes the society. It has forced characteristic, as logical consequence of law enforcement in the state and nation.

\subsection{Political Power as Law Converter}

The position of law as political activity cannot be denied anymore. In governmental structure, both power and politics is law converter tool. Both of them can change any form of law by using the argumentation of state interest. Based on das sein, law is power product and constitution. Law is legalization of political interests that are competed through political compromise or authority domination. In other words, it is the biggestpoliticalpower with various political interests. As law becomes political product, the law literature can be useless if the legislative attempt to cancel it [21].

Based on desire and necessity (das sollen), law refers not only to constitution, but also court decision (jurisprudence). Concerning the mutual influence between law and politics, in Mochtar Kusumaatmadja's (1970) opinion, both of them are in determinant. Politic without law was unjust, while law without politics was weakened [11]. This indicates that both of them cannot be separated one another. They are interconnected with various interests and goals, which is law enforcement in the future.

\section{Conclusion}

Power, politics, and law are part of society sub-system. However, power dominates law so that the law formation and enforcement is influence by authority holders' interests. Law in constitution is political authority product made by political power. Legislative role is a form of political power that can change, add, make, and cancel the implementation of law or constitution.

\section{References}

[1] Satjipto Rahardjo, IlmuHukum, Cetakan Keenam. Bandung.: PT. Citra AdityaBakti, 2006.

[2] Robert M. Mac Iver, The Web of Government, New York.: The Macmillan Company, 1965.

[3] Harold. D.Lasswell and Abraham. Kaplan, Power and Society, New Haven.: Yale University Press, 1970.

[4] L.J. van Appledoorn, Pengantar Ilmu Hukum, Jakarta.:Pradnya Paramitha, 2008.

[5] H.A. Semetko and P.M. Valkenburg, Framing European Politics: A Content Analysis of Press and Television News, Journal of Communication, vol. 50(2), pp. 93-109, 2000. http://dx.doi.org/10.1111/j.1460-2466.2000.tb02843.x

[6] Thomas, M.Franck, Fairnes in International Law and Institution, Oxford.: Clarendon Press, 1995.

[7] Bryan. A. Garner, Black's Law Dictionary, 7th ed. St. Paul Minn.: West Group, 1999.

[8] Kelsen, Hans, Teori Umum Tentang Hukum dan Negara, Bandung.:Nuansa dan Nusa Media, 2006,pp.360.

[9] Carl Joachim. Friedrich, Filsafat Hukum: Prespektif Historis, Cetakan Kedua. Bandung.:Nusamedia, 2008.

[10]Utrecht, Pengantar Dalam Hukum Indonesia, Jakarta. Jakarta.: Pustaka Sinar Harapan, 1983, pp. 28.

[11]Mochtar. Kusumaatmadja, Fungsi dan Perkembangan Hukum Dalam Pembangunan Nasional, Bandung.: Bina Cipta, 1970, pp.11.

[12]Hans. Kelsen, Pengantar Teori Hukum Murni, Bandung.: Nusa Media,2010.

[13] W. Friedman, Teori dan Filsafat Hukum. Susunan I. Telaah Kritis Atas Teori Hukum. Jakarta.: PT. Raja Grafindo Persada, 1990. 
[14] Ian. Mc. Leod, Legal Theory, London.: Macmillan Law Masters. 1999.

[15] John. Finch, Introduction to Legal Theory, London.: Sweet and Maxwell, 1974.

[16]Jan. Gijssels and Mark van Hoecke, Apakah Teori Hukum Itu, Bandung.: Laboratorium Hukum Fakultas Hukum, Universitas Katolik Parahyangan,1982.

[17] Saldi. Isra, Pergeseran Fungsi Legislasi, Jakarta.: Raja GrafindoPersada,2010, pp.78.

[18] Jimly A. Shidique, Teori Hans Kelsen Tentang Hukum. Jakarta: Sekretariat Jenderal dan Kepaniteraan Mahkamah Konstitusi RI, 2006.pp. 34

[19] Mahfud. MD, 2009. Politik Hukum. Jakarta: Raja GrafindoPersada, pp.7-8.

[20] Padmo. Wahyono, Indonesia Negara BerdasarkanatasHukum. Jakarta: Ghalia,1986.

[21]C.F.G. Sunaryati. Hartono, Politik Hukum Menuju Satu Sistem Hukum Nasional, Bandung.: Alumni Bandung, 1991. 